\title{
CJ-15,183, a New Inhibitor of Squalene Synthase Produced by a Fungus,
}

\section{Aspergillus aculeatus}

\author{
Shuzo Watanabe*, Hideo Hirai, Masaru Ishiguro, Takahito Kambara, Yasuhiro Kojima, \\ Tomoyuki Matsunaga, Hiroyuki Nishida, Yumiko Suzuki, Ayumu Sugiura, \\ H. James HaRwood, Jr. ${ }^{\dagger}$, Liang Hsiung Huang ${ }^{\dagger}$ and NaKao KoJma ${ }^{\dagger \dagger}$ \\ Exploratory Medicinal Sciences, PGRD, Nagoya Laboratories, Pfizer Pharmaceuticals Inc., \\ 5-Gochi 2, Taketoyo-cho, Chita-gun, Aichi 470-2393, Japan \\ ' PGRD, Groton Laboratories, Pfizer Inc., \\ Eastern Point Road, Groton, CT 06340, USA \\ ${ }^{\dagger}$ Faculty of Pharmacy, Meijo University, \\ 150 Yagotoyama, Tempaku-ku, Nagoya 468-8503, Japan
}

(Received for publication June 29, 2001)

\begin{abstract}
A new squalene synthase (SSase) inhibitor, CJ-15,183 (I) was isolated from the fermentation broth of a fungus, Aspergillus aculeatus CL38916. The compound potently inhibited rat liver and Candida albicans microsomal SSases and also inhibited the human enzyme. It also showed antifungal activities against filamentous fungi and a yeast. The structure. was determined to be an aliphatic tetracarboxylic acid compound consisting of an alkyl $\gamma$ lactone, malic acid and isocitric acid moieties by spectroscopic studies.
\end{abstract}

Sterol biosynthesis has been shown to be an attractive target for not only cholesterol lowering agents but also antifungal agents, and a number of inhibitors of sterol biosynthesis have been discovered. Pravastatin'), a 3hydroxy-3-methylglutaryl coenzyme A reductase (EC 1.1.1.34) inhibitor, is one of a group of very active antihypercholesterolemic agents. Terbinafine ${ }^{2)}$, a squalene epoxidase (EC 1.14.99.7) inhibitor, and zaragozic acids (squalestatins) $^{3,4)}$, SSase (EC 2.5.1.21) inhibitors, are a new group of potent antifungal agents. In the course of our screening program for discovery of sterol biosynthesis inhibitors, a fungus, Aspergillus aculeatus CL38916 was found to produce a new SSase inhibitor, CJ-15,183 (I). In this paper we report the taxonomy of the producing organism, and the fermentation, isolation, structure elucidation and biological activities of $\mathbf{I}$.

\section{Results}

Taxonomy

Cultural characteristics were as follows: Colonies on
Czapek sucrose agar, attaining $7.5 \mathrm{~cm}$ diam. in 11 days, dark vinaceous drab, dark purple-drab, dusky brown to blackish brown (XLV); deeply velutinous, smooth, with concentric zones of heavy sporulation, no exudate; reverse colorless; no soluble pigment. Colonies on malt extract agar, attaining $7.0 \mathrm{~cm}$ diam. in 11 days, dark purple-drab, deep brownish drab, to dusky drab (XLV); velutinous, smooth, moderate sporulation, without exudate; reverse colorless to pale cream; no soluble pigment. Colonies on cornmeal agar, attaining $7.0 \mathrm{~cm}$ diam. in 11 days, deep brownish drab to dusky drab (XLV); velutinous, smooth, with concentric zones of heavy sporulation; reverse colorless; no soluble pigment. Morphological properties were observed after 11 days of incubation on Czapek sucrose agar. Conidial heads were globose at first, then splitting into 3 to 8 defined columns which measured $15 \sim 40 \times 5 \sim 25 \mu \mathrm{m}$, with small heads measuring $10 \sim 40 \mu \mathrm{m}$ diam. and with conidial columns easily fallen off. Conidiophores were hyaline, but pale brown to brown below the vesicles, smooth, with a thick wall, measuring $0.9 \sim 2.3(\sim 3.2) \mathrm{mm} \times 10 \sim 17 \mu \mathrm{m}$. Vesicles were often elliptical when young, but globose or nearly so when

\footnotetext{
* Corresponding author: shuzo.watanabe@japan.pfizer.com
} 
matured, brown, and measured $40 \sim 80 \mu \mathrm{m}$ diam. They were fertile over the entire surface. Phialides were in a single series, and closely packed, measuring $7 \sim 13 \times 3 \sim 7 \mu \mathrm{m}$. Conidia were elliptical to globose, $4 \sim 5 \times 3 \sim 4 \mu \mathrm{m}$ or $3 \sim 4.2 \mu \mathrm{m}$ diam., conspicuously echinulate, and dark brown to purplish black in mass.

Under the alternate period of 12 hours light and 12 hours darkness, the strain CL38916 is characterized by the radiate conidial heads, the long conidiophores, the globose vesicles, the compact phialides arranged in a single series, the echinulate globose to elliptical spores, and the purplish black spores in mass. The growth was good from 20 to $37^{\circ} \mathrm{C}$ but was none at 45 and $50^{\circ} \mathrm{C}$. Under complete darkness, the spores in mass were brown-grayish black rather than purplish black. The conidiophores were generally shorter. The vesicles and the phialides were smaller. In darkness hyaline exudates were produced on cornmeal agar, potato dextrose agar, yeast extract - soluble starch agar, and phytone yeast extract agar; whereas they were absent under the alternate light and darkness. In darkness ochraceous buff or white sclerotia were produced on yeast extract-soluble starch agar and phytone yeast extract agar, respectively, but they were absent when incubated under the alternate light and darkness. Except for the production of sclerotia the strain CL38916 fits into the description of Aspergillus aculeatus, as defined by RAPER and FENNELL ${ }^{5)}$. Thus, the strain CL38916 is identified as a new strain of Aspergillus aculeatus Iizuka.

Isolation

The detection of I was monitored by HPLC using an ODS column as described in the experimental section. The fermentation broth (20 liters) was filtered with the aid of cerite, and then applied to a Diaion HP-20 column (500 ml, Mitsubishi Chemical Industries Ltd.). After washing the column with $50 \%$ aqueous acetone (2 liters), I was eluted with acetone ( 2 liters). The eluate was concentrated to dryness to yield an oily residue. The residue was dissolved in $\mathrm{MeCN}(10 \mathrm{ml})$ and subjected to preparative HPLC on an ODS column (YMC-Pack ODS AM-343, 20×250 mm, YMC Co., Ltd.) with $\mathrm{MeOH}-0.1 \% \mathrm{H}_{3} \mathrm{PO}_{4}$ in $\mathrm{H}_{2} \mathrm{O}(75: 25)$ at a flow rate of $10 \mathrm{ml} /$ minute. The active eluate was applied to a Sephadex LH-20 column $(500 \mathrm{ml}$, Amersham Pharmacia Biotech) with $\mathrm{MeOH}$, and the fractions containing I were applied to preparative HPLC on the same ODS column again with $\mathrm{MeOH}-0.1 \%$ TFA in $\mathrm{H}_{2} \mathrm{O}$ $(80: 20)$ at a flow rate of $10 \mathrm{ml} /$ minute. The eluted peak was collected and concentrated to yield $32.2 \mathrm{mg}$ of $\mathbf{I}$ as colorless oil.

\section{Physico-chemical Properties}

The physico-chemical properties of I are summarized in Table 1. The molecular formula of I was determined to be $\mathrm{C}_{28} \mathrm{H}_{38} \mathrm{O}_{13}$ by negative ion HRFAB-MS. The UV spectrum showed no characteristic UV absorption above $210 \mathrm{~nm}$. The IR spectra exhibited the presence of a hydroxyl $\left(3450 \mathrm{~cm}^{-1}\right)$ and a carbonyl $\left(1740 \mathrm{~cm}^{-1}\right)$ group.

\section{Structure Elucidation}

The ${ }^{13} \mathrm{C}$ NMR spectrum of I showed total 28 carbons which were classified to one methyl, ten methylenes, two methines, two oxymethines, six $s p^{2}$ methines, one oxyquarternary carbon and six carbonyl carbons, respectively by DEPT experiments. The NMR spectral data of $\mathbf{I}$ are summarized in Table 2.

Table 1. Physico-chemical properties of CJ-15,183 (I).

\begin{tabular}{ll}
\hline Appearance & Colorless oil \\
{$[\alpha]_{\mathrm{D}}\left(26^{\circ} \mathrm{C}\right)$} & $23.3^{\circ}(\mathrm{c} 0.06, \mathrm{MeOH})$ \\
Molecular formula & $\mathrm{C}_{28} \mathrm{H}_{38} \mathrm{O}_{13}$ \\
Molecular weight & 582 \\
HRFAB-MS $(\mathrm{m} / z)$ & \\
$\quad$ Found: & $581.2237(\mathrm{M}-\mathrm{H})^{-}$ \\
$\quad$ Calcd.: & $581.2234\left(\right.$ for $\left.\mathrm{C}_{28} \mathrm{H}_{37} \mathrm{O}_{13}\right)$ \\
UV $\lambda_{\max (\mathrm{MeOH})}$ & End absorption \\
IR $v_{\max }(\mathrm{KBr}) \mathrm{cm}^{-1}$ & $3450,2920,1740,1400,1255,1180$ \\
Solubility & \\
$\quad$ Soluble: & $\mathrm{MeOH}, \mathrm{MeCN}$, Acetone, DMSO \\
$\quad$ Insoluble: & $\mathrm{H}_{2} \mathrm{O}$ \\
&
\end{tabular}


Table 2. ${ }^{1} \mathrm{H}$ and ${ }^{13} \mathrm{C}$ NMR data for CJ-15,183 (I).

\begin{tabular}{|c|c|c|}
\hline Position & $\begin{array}{c}{ }^{13} \mathrm{C} \text { Chemical shift } \delta \\
\text { (multiplicity) }\end{array}$ & $\begin{array}{l}{ }^{1} \mathrm{H} \text { Chemical shift } \delta \\
\text { (multiplicity, } J=\mathrm{Hz} \text { ) }\end{array}$ \\
\hline 1 & $175.5(s)$ & \\
\hline 2 & $41.9(\mathrm{t})$ & $3.15(1 \mathrm{H}, \mathrm{d}, 16.5), 3.56(1 \mathrm{H}, \mathrm{d}, 16.5)$ \\
\hline 3 & $76.5(s)$ & \\
\hline 4 & $47.7(\mathrm{~d})$ & $3.08(1 \mathrm{H}, \mathrm{dd}, 5.9,9.5)$ \\
\hline 5 & $31.9(t)$ & $2.06(1 \mathrm{H}, \mathrm{m}), 2.40(1 \mathrm{H}, \mathrm{m})$ \\
\hline 6 & $81.3(\mathrm{~d})$ & $4.98(1 \mathrm{H}, \mathrm{m})$ \\
\hline 7 & $129.8(d)$ & $5.55(1 \mathrm{H}, \mathrm{dd}, 7.0,15.0)$ \\
\hline 8 & $135.6(d)$ & $5.80(1 \mathrm{H}, \mathrm{dd}, 6.6,15.0)$ \\
\hline 9 & $33.1(t)$ & $2.14(2 \mathrm{H}, \mathrm{m})$ \\
\hline 10 & $27.6(t)$ & $2.17(2 \mathrm{H}, \mathrm{m})$ \\
\hline 11 & $129.8(\mathrm{~d})$ & $5.55(1 \mathrm{H}, \mathrm{m})$ \\
\hline 12 & $129.7(d)$ & $5.35(1 \mathrm{H}, \mathrm{m})$ \\
\hline 13 & $26.5(t)$ & $2.77(2 \mathrm{H}, \mathrm{dd}, 5.1,7.7)$ \\
\hline 14 & $128.8(\mathrm{~d})$ & $5.32(1 \mathrm{H}, \mathrm{m})$ \\
\hline 15 & $131.1(\mathrm{~d})$ & $5.35(1 \mathrm{H}, \mathrm{m})$ \\
\hline 16 & $28.1(t)$ & $2.05(2 \mathrm{H}, \mathrm{m})$ \\
\hline 17 & $30.4(t)$ & $1.34(2 \mathrm{H}, \mathrm{m})$ \\
\hline 18 & $32.9(t)$ & $1.34(2 \mathrm{H}, \mathrm{m})$ \\
\hline 19 & $23.6(t)$ & $1.34(2 \mathrm{H}, \mathrm{m})$ \\
\hline 20 & $14.4(\mathrm{q})$ & $0.90(3 \mathrm{H}, \mathrm{t}, 6.9)$ \\
\hline 21 & $170.7(\mathrm{~s})$ & \\
\hline 22 & $177.6(\mathrm{~s})$ & \\
\hline 23 & $171.1(\mathrm{~s})$ & \\
\hline 24 & $73.2(d)$ & $5.42(1 \mathrm{H}, \mathrm{d}, 3.7)$ \\
\hline 25 & $44.0(\mathrm{~d})$ & $3.50(1 \mathrm{H}, \mathrm{ddd}, 3.7,5.1,9.2)$ \\
\hline 26 & $32.6(t)$ & $2.54(1 \mathrm{H}, \mathrm{dd}, 5.1,17.2), 2.75(1 \mathrm{H}, \mathrm{dd}, 9.2,17.2)$ \\
\hline 27 & $175.0(\mathrm{~s})$ & \\
\hline 28 & $173.4(\mathrm{~s})$ & \\
\hline
\end{tabular}

Chemical shifts are shown with reference to $\mathrm{CD}_{3} \mathrm{OD}$ as $3.30 \mathrm{ppm}$ for ${ }^{1} \mathrm{H} \mathrm{NMR}$ and as 49.8 ppm for ${ }^{13} \mathrm{C}$ NMR.

From the analysis of ${ }^{1} \mathrm{H}-{ }^{1} \mathrm{H}$ DQF-COSY spectral data, four partial structures drawn with bold lines in Fig. 1, were confirmed. The connections between these partial structures, and six carbonyl carbons, one methylene ( $\mathrm{C}-2)$ and one oxyquarternary carbon (C-3) were examined by HMBC and selective INEPT experiments.

As shown in Fig. 1, the unsaturated alkyl chain $(C$ $7 \sim 20)$ was determined by correlations from $\mathrm{H}-16(\delta 2.05)$ and $\mathrm{H}-20(\delta 0.90)$ to $\mathrm{C}-18(\delta 32.9)$, and from $\mathrm{H}-9(\delta 2.14)$ to $\mathrm{C}-10(\delta$ 27.6) and $\mathrm{C}-11(\delta$ 129.8) in the HMBC experiments. Correlations from $\mathrm{H}-4(\delta 3.08), \mathrm{H}-5$ ( $\delta 2.06$ and 2.40) and H-6 $(\delta 4.98)$ to C-22 $(\delta 177.6)$ indicated the presence of a $\gamma$-lactone moiety. The malic acid moiety ( $\mathrm{C}-1$ $\sim \mathrm{C}-3$ and $\mathrm{C}-21$ ) was determined by correlations from $\mathrm{H}-2$ $(\delta 3.15)$ to $\mathrm{C}-1(\delta 175.5), \mathrm{C}-3(\delta 76.5)$ and $\mathrm{C}-21(\delta 170.7)$. The connection between the $\gamma$-lactone and malic acid moieties (linkage between C-3 and C-4) was determined by correlations from $\mathrm{H}-4$ to $\mathrm{C}-3$ and $\mathrm{C}-21$ in the selective INEPT experiments. Correlations from $\mathrm{H}-26(\delta 2.54$ and $2.75)$ to $\mathrm{C}-27(\delta 175.0)$ and $\mathrm{C}-28(\delta 173.4)$, from $\mathrm{H}-25(\delta$ $3.50)$ to $\mathrm{C}-23(\delta 171.1), \mathrm{C}-27$ and $\mathrm{C}-28$, and from $\mathrm{H}-24(\delta$ 5.42) to $\mathrm{C}-23$ and $\mathrm{C}-28$ supported the presence of an isocitric acid moiety $(\mathrm{C}-23 \sim \mathrm{C}-28)$. The connection between the isocitric acid and malic acid moieties (linkage between $\mathrm{C}-21$ and $\mathrm{C}-24$ ) was confirmed by correlations from $\mathrm{H}-24$ to $\mathrm{C}-21$.

The geometry of double bond at C-7 was assigned as $E$ configuration because of the coupling constant $\left(J_{7,8}=15.0\right.$ $\mathrm{Hz}$ ). In addition, the geometries of double bonds at $\mathrm{C}-11$ and $\mathrm{C}-14$ were deduced to be both $Z$ configuration on the basis of the chemical shift value of the allyic methylene at C-13 $(\delta 26.5)^{6}$. The results described above and the molecular formula for $\mathbf{I}\left(\mathrm{C}_{28} \mathrm{H}_{38} \mathrm{O}_{13}\right)$ show five additional hydrogens, and therefore suggest the presence of one 
Fig. 1. Summary of ${ }^{1} \mathrm{H}^{-}{ }^{1} \mathrm{H}$ DQF-COSY, HMBC and selective INEPT experiments of CJ-15,183 (I).

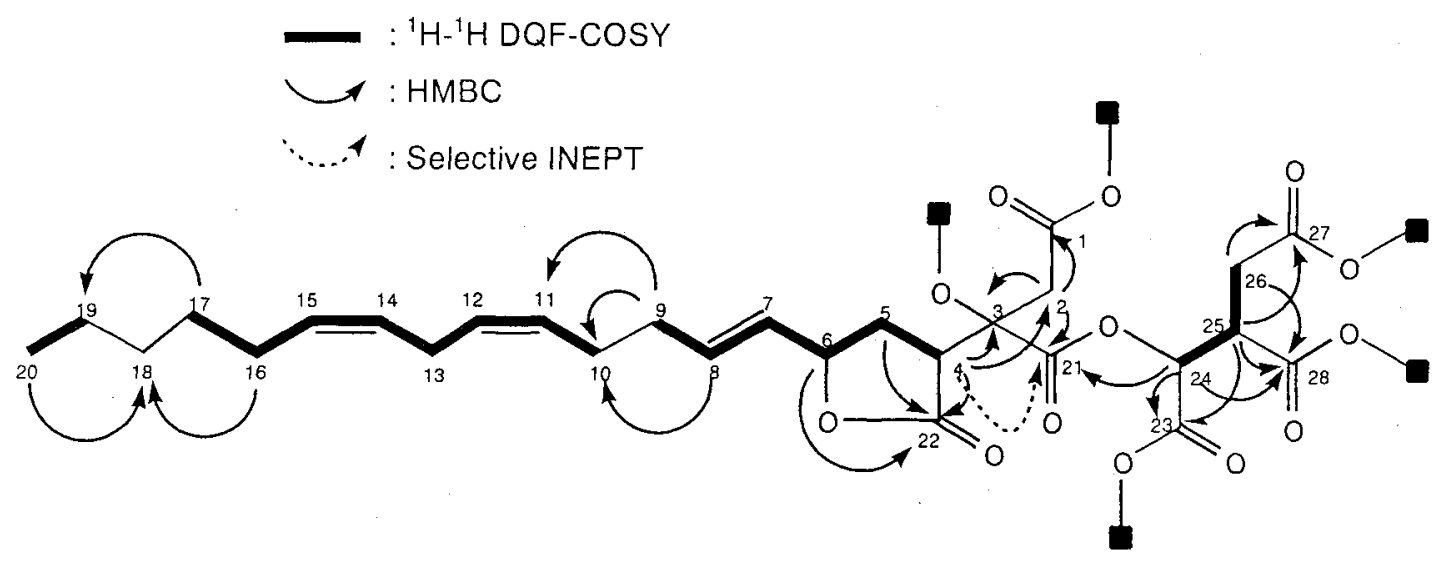

Fig. 2. Structures of CJ-15,183 (I) and its related compounds.

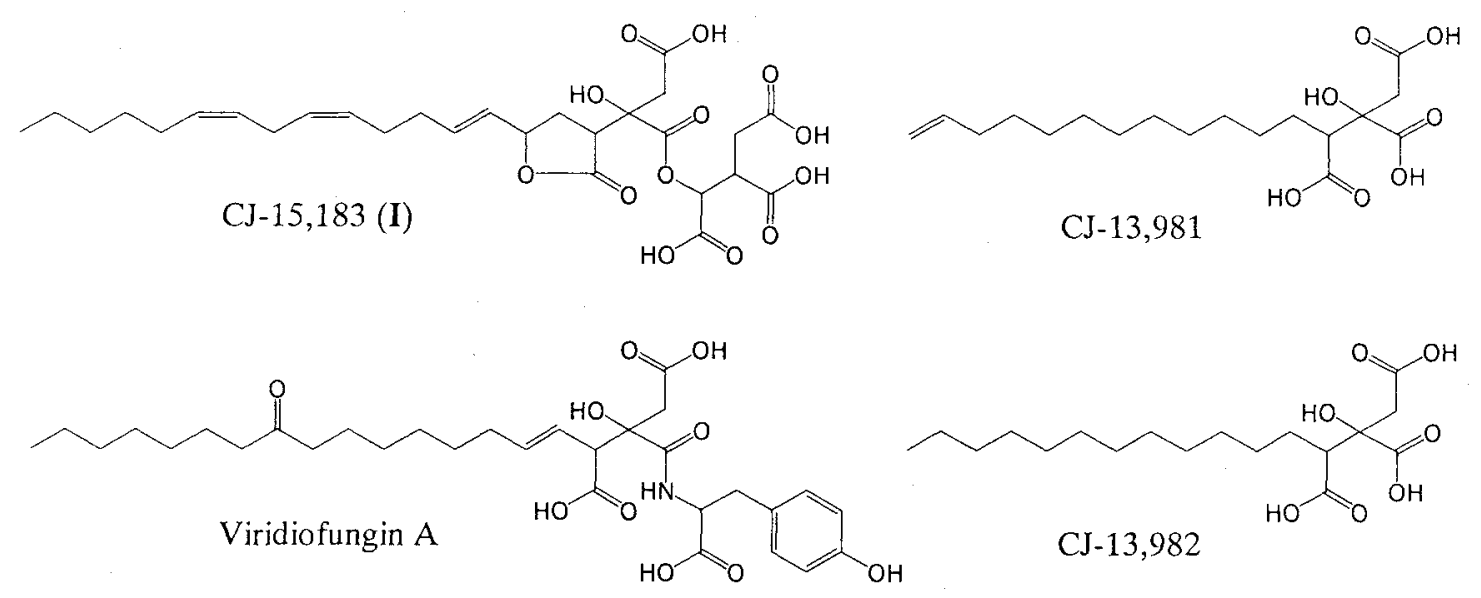

Table 3. SSase inhibitory activities of CJ-15,183 (I) and its-related compounds.

\begin{tabular}{lccc}
\hline & \multicolumn{3}{c}{ SSase inhibition $\left(\mathrm{IC}_{50}, \mu \mathrm{M}\right)$} \\
\cline { 2 - 4 } & Rat liver & Human liver & Candida albicans \\
\hline CJ-15,183 (I) & 5.2 & 98 & 8.6 \\
CJ-13,981 & 4.2 & 2.8 & 25 \\
CJ 13,982 & 2.2 & 1.1 & 5.6 \\
\hline
\end{tabular}

hydroxyl group and four carboxylic acid residues in the molecule. Thus, the structure of $\mathbf{I}$ was determined as shown in Fig. 2.

\section{Biological Activities}

As shown in Table 3, I inhibited rat liver, human liver and Candida albicans microsomal SSases at the $\mathrm{IC}_{50} \mathrm{~s}$ of 
Table 4. Antifungal activities of CJ-15,183 (I).

\begin{tabular}{lcccc}
\hline \multirow{2}{*}{ Tested strain } & \multicolumn{4}{c}{ Diameter of inhibition zone ${ }^{1)}(\mathrm{mm})$} \\
\cline { 2 - 5 } & $\mathrm{CJ}-15,183$ (I) & ZA $^{2)}$ & $\mathrm{FLZ}^{3)}$ & AMB $^{4)}$ \\
\hline Aspergillus flavus ATCC 26938 & 10 & 37 & $\mathrm{nz}$ & 12 \\
Aspergillus fumigatus ATCC 24681 & 22 & 43 & $\mathrm{nz}$ & $\mathrm{nz}$ \\
Aspergillus niger ATCC 16404 & $\mathrm{nz}$ & $\mathrm{nz}$ & $\mathrm{nz}$ & 15 \\
Fusarium oxysporum ATCC 48112 & 12 & 12 & $\mathrm{nz}$ & 10 \\
Byssochlamys fulva ATCC 28799 & 21 & 10 & $\mathrm{nz}$ & 24 \\
Candida albicans ATCC 58716 & 9 & 14 & 34 & 23 \\
Candida parapsilosis ATCC 22019 & 9 & 22 & 34 & 14 \\
Candida tropicalls ATCC 18213 & 11 & 9 & 24 & 11 \\
Cryptococcus albidus ATCC 32420 & 9 & 19 & 31 & 14 \\
Saccharomyces cerevisiae ATCC 12341 & 21 & 33 & 9 & 20 \\
\hline
\end{tabular}

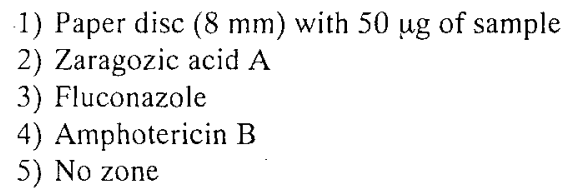

$5.2,98$ and $8.6 \mu \mathrm{M}$, respectively.

Compound I showed antifungal activities against Aspergillus fumigatus ATCC 24681, Byssochlamys fulva ATCC 28799 and Saccharomyces cerevisiae ATCC 12341 (Table 4).

\section{Discussion}

The new SSase inhibitor, CJ-15,183 (I), structurally belongs to the type of alkylcitric acid compounds such as $\mathrm{CJ}-13,981^{7)}, \mathrm{CJ}-13,982^{7)}$ and viridiofungin $\mathrm{A}^{8)}$ (Fig. 2). The biosynthetic pathway of these compounds is considered to arise by condensation of the carbonyl group of oxaloacetate with the $\alpha$-methylene group of a fatty acid ${ }^{9,10)}$, suggesting that $\mathbf{I}$ also arises by the same biosynthetic pathway with the formation of $\gamma$-lactone ring and the addition of isocitrate (24-OH) to oxaloacetate (C-21).

Compound I inhibited rat liver microsomal SSase with an $\mathrm{IC}_{50}$ of $5.2 \mu \mathrm{M}$, but showed 20 times less activity against human enzyme, whereas CJ-13,981 and CJ-13,982 exhibited same potency to each SSase. It is assumed that the difference of affinity to each SSase or stability of $\mathbf{I}$ in human SSase assay might cause the low potency to human SSase of $\mathbf{I}$.

Viridiofungin A inhibited rat and Candida albicans microsomal SSases with $\mathrm{IC}_{50} \mathrm{~s}$ of 15 and $11.8 \mu \mathrm{M}$, respectively ${ }^{11)}$. Additionally it showed a broad antifungal spectrum against filamentous fungi and a yeast ${ }^{12)}$. These results lead to the conclusion that the alkylcitric acid compounds have same potency to rat and Candida albicans microsomal SSases, and show broad antifungal spectrum against filamentous fungi and a yeast, but show less activity compared to the zaragozic acids.

\section{Experimental}

\section{General}

Spectral and physico-chemical data were obtained on the following instruments: UV, JASCO Ubest-30; IR, Shimadzu IR-470; optical rotations, JASCO DIP-370 with a $10 \mathrm{~cm}$ cell; NMR, JEOL JNM-GX270 updated with an LSI-11/73 host computer, TH-5 tunable probe and version 1.6 software; and LRFAB- and HRFAB-MS, JEOL MS-700 with a mastation data processing system. All NMR spectra were measured in $\mathrm{CD}_{3} \mathrm{OD}$ unless otherwise indicated and peak positions are expressed in parts per million (ppm) based on the internal standard of the $\mathrm{MeOH}$ peak at $3.30 \mathrm{ppm}$ for ${ }^{1} \mathrm{H}$ NMR and $49.8 \mathrm{ppm}$ for ${ }^{13} \mathrm{C}$ NMR. All FAB-MS spectra were measured using glycerol-matrix.

\section{Producing Microorganism}

The producing organism, strain CL38916 was isolated 
from a soil sample collected in Kira-cho, Hazu-gun, Aichi Prefecture, Japan. The culture was three-spot inoculated from a spore suspension of $0.2 \%$ agar onto plates of identification media, and the plates were incubated at $25^{\circ} \mathrm{C}$ for up to two weeks under compete darkness or cycles of alternate 12-hour lights and 12-hour darkness. The results were read at 11 days for cultural characteristics and 14 days for temperature studies. The colors were determined by comparisons with color chips from RIDGWAY ${ }^{13)}$. Identification media used are Czapek-sucrose agar ${ }^{5)}$, cornmeal agar ${ }^{14)}$, malt extract agar ${ }^{5)}$, phytone yeast extract agar (BBL), potato dextrose agar (peeled potato $100 \mathrm{~g}$, dextrose $10 \mathrm{~g}$, agar $20 \mathrm{~g}$, tap water 1 liter), yeast extract soluble starch agar ${ }^{15}$. Malt extract agar was used for temperature studies.

\section{Fermentation}

Aspergillus aculeatus CL38916 was maintained on potato dextrose agar slant (Difco). A vegetative cell suspension from the slant was used to inoculate a $500-\mathrm{ml}$ Erlenmeyer flask containing $100 \mathrm{ml}$ of a seed medium (potato dextrose broth $2.4 \%$, yeast extract $0.5 \%$ and agar $0.1 \%$ ). The flask was shaken at $26^{\circ} \mathrm{C}$ for 4 days on a rotary shaker $(7-\mathrm{cm}$ throw at $250 \mathrm{rpm})$. Five $\mathrm{ml}$ aliquot was inoculated into a $500-\mathrm{ml}$ Erlenmeyer flask containing $150 \mathrm{ml}$ of the seed medium and shaken at $26^{\circ} \mathrm{C}$ for 3 days. The second seed culture was inoculated into a 6-liter jar fermentor containing 3 liters of a production medium (sucrose $2 \%$, potato starch $10 \%$, casamino acid $1 \%$, $\mathrm{KH}_{2} \mathrm{PO}_{4} 0.5 \%$ and $\mathrm{MgSO}_{4} \cdot 7 \mathrm{H}_{2} \mathrm{O} 0.03 \%$ ). The fermentation was carried out at $26^{\circ} \mathrm{C}$ for 14 days at an aeration rate of 3 liters/minute and an agitation rate of $1,750 \mathrm{rpm}$.

\section{HPLC Analysis}

HPLC analysis was performed on a Hewlett Packard HP1090 system. Samples were subjected to an ODS column (YMC-pack ODS AM-312, 6.0×150 mm, YMC Co., Ltd.) maintained at $42^{\circ} \mathrm{C}$ and eluted with $\mathrm{MeOH}-$ $0.1 \%$ TFA in $\mathrm{H}_{2} \mathrm{O}(80: 20)$ at a flow rate of $0.8 \mathrm{ml} / \mathrm{minute}$. Compound I was monitored by absorbance at $210 \mathrm{~nm}$. Under these conditions, I was eluted at the retention time of 5.8 minutes.

\section{Preparation of Rat Hepatic Microsomes}

Livers freshly obtained from Wistar rats (Charles River) were rinsed in ice-cold PBS and briefly homogenized in buffer A (50 mM MOPS- $\mathrm{NaOH}$; $\mathrm{pH} 7.4,10 \mathrm{mM} \mathrm{MgCl}_{2}$, $1 \mathrm{mM}$ EDTA, $10 \mathrm{~mm}$ dithiothreitol) containing the protease inhibitors $(500 \mu \mathrm{M}$ PMSF, $10 \mu \mathrm{M}$ aprotinin, $10 \mu \mathrm{M}$ leupeptin, $10 \mu \mathrm{M}$ chymostatin). The homogenate was centrifuged at $3,000 \times g$ for 20 minutes at $4^{\circ} \mathrm{C}$. The supernatant was recentrifuged at $20,000 \times g$ for 30 minutes at $4^{\circ} \mathrm{C}$. The supernatant was again recentrifuged at $100,000 \times g$ for 60 minutes at $4^{\circ} \mathrm{C}$. After centrifugation, the supernatant was removed and the pellet was suspended in buffer A. This microsomal preparation had a protein concentration of about $13.2 \mathrm{mg} / \mathrm{ml}$. The microsomal suspensions were stored at $-70^{\circ} \mathrm{C}$. Under these conditions, SSase activity was stable for at least several months.

\section{SSase Activity}

Assays were performed on 96-well microtiter plates in a total volume of $50 \mu \mathrm{l}$ containing $50 \mathrm{~mm}$ MOPS-NaOH (pH 7.4), $10 \mathrm{~mm}$ KF, $10 \mathrm{mM} \mathrm{MgCl}_{2}, 2 \mathrm{~mm}$ CHAPS, $10 \mathrm{~mm}$ dithiothreitol, $0.5 \mathrm{~mm} \mathrm{NADPH}, 50 \mathrm{~mm}$ ascorbate, 20 units $/ \mathrm{ml}$ ascorbate oxidase, $2 \mathrm{mM}$ glucose- 6 -phosphate, 20 units/ml glucose-6-phosphate dehydrogenase, rat hepatic microsomes and $6 \mu \mathrm{M}\left[1-{ }^{3} \mathrm{H}\right] \mathrm{FPP}$. After incubation at room temperature for 30 minutes, the reaction was terminated by the addition of $20 \mu \mathrm{l}$ of 1 -propanol containing unlabeled $1 \%$ squalene. Thirty microliters of reaction mixture was applied onto a polyester-backed silica gel TLC sheet (Sigma; $10 \mathrm{~cm} \times 10 \mathrm{~cm}$ ) which was developed with hexaneEtOAc (7:3). After drying, radioactivity in zone containing the squalene $(\mathrm{Rf}=0.8)$ was scraped and measured by a scintillation counter ${ }^{16,17)}$.

\section{Antifungal Activity}

Antifungal assay was tested using paper dises (i.d. $8 \mathrm{~mm}$, ADVANTEC). Aspergillus, Fusarium, Byssochlamys, Candida and Saccharomyces species were grown on potato dextrose agar medium (Difco) and Cryptococcus albidus ATCC 32420 was grown on sabouraud agar medium (Nissui). Antimicrobial activity was observed after 24-hour incubation at $27^{\circ} \mathrm{C}$ for yeasts and after 48 -hour incubation for fungi.

\section{References}

1) Tsujita, Y.; M. Kuroda, Y. Shimada, K. Tanzawa, M. Arai, I. Kaneko, M. Tanaka, H. Masuda, C. Tarumi, Y. WATANABE \& S. FUJI: CS-514, a competitive inhibitor of 3-hydroxy-3-methylglutaryl coenzyme A reductase: tissue-selective inhibition of sterol synthesis and hypolipidemic effect on various animal species. Biochem. Biophys. Acta 877: 50 60, 1986

2) Petranyi, G.; N. S. Ryder \& A. Stuetz: Allylamine derivatives: new class of synthetic antifungal agents inhibiting fungal squalene epoxidase. Science 224: $1239 \sim 1241,1984$

3) Baxter, A.; B. J. Fitzgerald, J. L. Hutson, A. D. McCarthy, J. M. Motteram, B. C. Ross, M. Sapra, M. A. Snowden, N. S. Watson, R. J. Williams \& C. 
WRIGHT: Squalestatin 1, a potent inhibitor of squalene synthase, which lowers serum cholesterol in vivo. J. Biol. Chem. 267: 11705 11708, 1992

4) Bergstrom, J. D.; M. M. Kurtz, D. J. Rew, A. M. Amend, J. D. Karkas, R. G. Bostedor, V. S. Bansal, C. Dufresne, F. L. Vanmiddlesworth, O. D. Hensens, J. M. LIESCH, D. L. ZINK, K. E. WILSON, J. ONISHI, J. A. Milligan, G. Bills, L. Kaplan, M. N. Omstead, R. G. Jenkins, L. Huang, M. S. Meinz, L. Quinn, R. W. Burg, Y. L. Kong, S. Mochales, M. Mojena, I. Martin, F. Pelaez, M. T. Drez \& A. W. Alberts: Zaragozic acids: a family of fungal metabolites that are picomolar competitive inhibitors of squalene synthase. Proc. Natl. Acad. Sci. USA 90: 80 84, 1993

5) Raper, K. B. \& D. I. Fennell: The genus Aspergillus, Baltimore. The Williams and Wilkins: 686,1965

6) Wenkert, E.; B. L. Buckwalter, I. R. Burfitt, M. J. Gasic, H. E. Gottlieb, E. W. Hagaman, F. M. Schell \& P. M. Wovkulich: Carbon-13 nuclear magnetic resonance spectroscopy of naturally occurring substances. Topics in Carbon-13 NMR Sectroscopy 2: $81 \sim 121,1975$

7) Watanabe, S.; H. Hirai, N. Yoshikawa, A. Sugiura, T. Kambara, H. NishidA, Y. YamauchI, Y. KoJIma, H. J. HaRWOOD, Jr., L. H. HuAng \& N. KOJIMA: CJ-13,981 and $\mathrm{CJ}-13,982$, new squalene synthase inhibitors. $\mathrm{J}$. Antibiotics, in preparation

8) Harris, G. H.; E. T. T. Jones, M. S. Meinz, M. N. Omstead, G. L. Helms, G. F. Bills, D. Zink \& K. E. WILSON: ' Isolation and structure elucidation of viridiofungins $\mathrm{A}, \mathrm{B}$ and $\mathrm{C}$. Tetrahedron Lett. 34: $5235 \sim 5238,1993$
9) Tanabe, M.; T. Hamasaki, Y. Suzuki \& F. L. Jonson: Biosynthetic studies with carbon-13. Fourier transform nuclear magnetic resonance spectra of the metabolite avenaciolide. J. C. S. Chem. Comm. 212 213, 1973

10) McCorkindale, N. J.; W. P. Blackstock, G. A. Johnston, T. P. RoY \& J. A. Troke: Biosynthesis of canadensolide, ethisolide and related metabolites. 11th IUPAC Int. Symp. Chem. Nat. Prod. 1: 151 154, 1978

11) Harris, G. H.: Biological active compounds isolated from aerobic fermentation of Trichoderma viride. WO9418157-A1, Jan. 25, 1994

12) Onishi, J. C.; J.A. Milligan, A. Basilio, J. Bergstrom, J. Curotto, L. Huang, M. Meinz, M. Nallin-Omstead, F. Pelaez, D. Rew, M. Salvatore, J. Thompson, F. VICENTE \& M. B. KURTZ: Antimicrobial activity of viridiofungins. J. Antibiotics 50: 334 337, 1997

13) RIDGWAY, R.: Color standards and color nomenclature. Publ. by the author, Washington, D.C., p. 43, 1912

14) Carmichael, J. W.: Geotrichum candidum. Mycologia 49: 820 830, 1957

15) EMERson, R.: Mycological organization. Mycologia 50: 589 621, 1958

16) HaRwood, Jr., H. J.: Measurement of enzymatic activity in 96-well format using TopCount microplate scintillation counting technology. Anal. Biochem. 226: 268 278, 1995

17) Petras, S. F.; S. Lindsey \& H. J. HaRWOOD, Jr.: HMGCoA reductase regulation: use of structurally diverse first half-reaction squalene synthetase inhibitors to characterize the site of mevalonate-derived nonsterol regulator production in cultured IM-9 cells. J. Lipid Res. 40: $24 \sim 38,1999$ 